\title{
Pengaruh Motivasi, Dukungan Manajemen dan Integritas terhadap Kualitas Audit Internal Aparat Inspektorat dalam Pengawasan Keuangan Daerah (Studi Empiris Pada Inspektorat Kota Manado)
}

\author{
TARIDA ELISA BUTARBUTAR ${ }^{1}$, LINTJE KALANGI ${ }^{2}$, HENDRIK GAMALIEL ${ }^{3}$ \\ Program Studi Magister Akuntansi Fakultas Ekonomi dan Bisnis Universitas Sam Ratulangi \\ Email: lisatari.lt@gmail.com ${ }^{1}$, lintje_kalangi@yahoo.com² ${ }^{2}$,hendrik_gamaliel@unsrat.ac.id ${ }^{3}$
}

\begin{abstract}
Internal Auditor is a profession of community trust. The great trust of the Community requires internal auditors to pay attention to the quality of audit. Internal auditors are expected to have a large enough role to assist in achieving organizational objectives. This research aims to analyse and empirically prove the influence of motivation, management support, and integrity of the internal audit quality of inspectorate apparatus in the regional financial supervision. This is a quantitative research. It employed primary data collected by questionnaires. Respondents in the study were internal supervisory officers working on the Inspectorate of Manado City. 45 respondents were selected as respondents, which were directly involved in the examination activities. Data was analyzed by multiple linear regression and run by SPSS program version 22. The results showed that: 1). Motivation has a significant positive effect on the quality of internal audit of inspectorate apparatus in the financial supervision of Manado City. 2). Management support significantly and positively influence the quality of internal audit of inspectorate apparatus in the financial supervision of Manado City. 3). Integrity has a significant positive effect on the quality of internal audit of inspectorate apparatus in the financial supervision of Manado City.
\end{abstract}

Key Words: Motivation, Management Support, Integrity, Audit Quality.

Abstrak. Auditor internal merupakan suatu profesi kepercayaan masyarakat. Kepercayaan yang besar dari masyarakat mengharuskan auditor internal memperhatikan kualitas audit yang dihasilkan. Auditor internal diharapkan mempunyai peran yang cukup besar untuk membantu dalam mencapai tujuan organisasi. Penelitian ini bertujuan untuk menganalisis dan membuktikan secara empiris Pengaruh motivasi, dukungan manajemen, dan integritas terhadap kualitas audit internal aparat inspektorat dalam pengawasan keuangan daerah. Jenis penelitian ini adalah penelitian kuantitatif, dengan menggunakan data primer melalui kuesioner. Responden dalam penelitian ini adalah aparat pengawas internal yang bekerja pada Inspektorat Kota Manado. Sampel yang digunakan adalah sebanyak 45 responden, yang terlibat langsung dalam kegiatan pemeriksaan. Data dianalisis menggunakan analisis regresi linier berganda dan pengujian data dilakukan dengan dibantu oleh program SPSS versi 22. Hasil penelitian menunjukkan bahwa: 1). Motivasi berpengaruh positif signifikan terhadap kualitas audit internal aparat inspektorat dalam pengawasan keuangan daerah Kota Manado. 2). Dukungan manajemen berpengaruh positif signifikan terhadap kualitas audit internal aparat inspektorat dalam pengawasan keuangan daerah Kota Manado. 3). Integritas berpengaruh positif signifikan terhadap kualitas audit internal aparat inspektorat dalam pengawasan keuangan daerah Kota Manado.

Kata Kunci: Motivasi, Dukungan Manajemen, Integritas, Kualitas Audit. 


\section{Pendahuluan}

Di Indonesia, reformasi pengelolaan keuangan negara ditandai dengan pemberlakuan UndangUndang Nomor 17 Tahun 2003 tentang keuangan negara yang mewajibkan instansi pemerintah pusat dan daerah membuat laporan keuangan dalam setiap pertanggungjawaban pelaksanaan APBN/D kepada DPR/D. Pemerintah daerah wajib membuat Laporan Kinerja Pemerintah Daerah (LKPD), laporan ini adalah laporan kinerja yang dirancang untuk publik dan dipublikasikan di media atau tempat-tempat umum. Laporan ini diperlukan agar rakyat mengetahui apa yang sudah dilakukan pemerintah daerahnya.

Peraturan Presiden Nomor 29 Tahun 2014 memberikan kewenangan lebih kepada Aparat Pengawasan Intern Pemerintah (APIP) yakni inspektorat untuk berperan dalam pencapaian kinerja pemerintah daerah. Inspektorat melakukan reviu atas laporan kinerja dalam rangka meyakinkan keandalan informasi yang disajikan. Inspektorat yang merupakan bagian dari audit internal berperan untuk menilai apakah sistem pengawasan yang telah ditetapkan berjalan dengan akurat serta setiap bagian benar-benar melaksanakan kebijakan sesuai dengan rencana dan prosedur yang telah ditetapkan.

Auditor internal merupakan suatu profesi kepercayaan masyarakat. Kepercayaan yang besar dari masyarakat mengharuskan auditor internal memperhatikan kualitas audit yang dihasilkan. Kualitas audit menurut De Angelo (1981) yang dikutip Alim, Hapsari, dan Purwanti (2017) adalah sebagai probabilitas bahwa auditor akan menemukan dan melaporkan pelanggaran pada sistem akuntansi klien. Probabilitas untuk menemukan pelanggaran tergantung pada kemampuan teknis auditor dan probabilitas melaporkan pelanggaran tergantung pada independensi auditor.

Government Accountability Office (2005), mendefinisikan kualitas audit sebagai ketaatan terhadap standar profesi dan ikatan kontrak selama melakukan audit. Auditor internal diharapkan mempunyai peran yang cukup besar untuk membantu dalam mencapai tujuan dengan menggunakan pendekatan yang sistematis dalam pengelolaan resiko. Simanjuntak (2008) menjelaskan bahwa kualitas audit adalah pemeriksaan yang sistematis dan independensi untuk menentukan aktivitas, mutu dan hasilnya sesuai dengan pengaturan yang telah direncanakan dan apakah pengaturan tersebut diimplementasikan secara efektif dan sesuai dengan tujuan.

Terdapat enam faktor yang mempengaruhi kualitas audit yaitu, kompetensi, pengalaman, obyektifitas, independensi, integritas, dan yang terakhir motivasi (Turangan, 2016). Integritas berpengaruh positif dan signifikan terhadap kualitas audit artinya semakin baik integritas maka semakin baik kualitas audit yang dihasilkan. integritas tersebut harus didukung oleh kepribadian auditor yang dilandasi oleh unsur jujur, berani, bijaksana, dan bertanggung jawab. Sedangkan, motivasi berpengaruh positif dan signifikan terhadap kualitas audit sehingga semakin tinggi motivasi maka kualitas audit yang dihasilkan akan semakin baik.

Saat ini inspektorat kota Manado dituntut untuk lebih meningkatkan kualitas pengawasan dan kualitas audit dalam mewujudkan tata kelola pemerintahan yang baik. Semakin besar suatu negara semakin banyak pula tuntutan dari masyarakat untuk pemerintah yang disiplin, bersih dan transparan. Berdasarkan Laporan Hasil Pemeriksaan (LHP) Badan Pemeriksa Keuangan (BPK), atas Laporan Keuangan Pemerintah Daerah (LKPD) kota Manado 2016 banyak menemukan permasalahan, terkait kelemahan sistem pengendalian intern dan ketidak patuhan terhadap ketentuan peraturan perundangundangan, kerugian keuangan maupun administrasi. Oleh karena itu, BPK memberikan opini Wajar Dengan Pengecualian (WDP) pada tahun 2016, sedangkan di tahun 2017 kota Manado berhasil memperoleh opini WTP, opini tersebut didapat dengan keterangan masih perlu ada pendampingan (Wolajan, 2018). Dengan adanya perubahan dari opini WTP turun ke opini WDP hal ini menyebabkan kualitas audit yang dilakukan oleh auditor aparat inspektorat Kota Manado masih menjadi perhatian masyarakat, dari beberapa kasus yang menjadi temuan BPK yang tidak ditemukan oleh inspektorat sebagai auditor internal di Kota Manado.

Hal tersebut yang menjadi motivasi dalam penelitian ini, sehingga peneliti ingin meneliti variabel motivasi, dukungan manajemen dan integritas terhadap kualitas audit internal dalam pengawasan keuangan daerah.

Tujuan dari penelitian ini adalah untuk menganalisis dan membuktikan secara empiris:

1. Pengaruh motivasi terhadap kualitas audit internal aparat inspektorat dalam pengawasan keuangan daerah Kota Manado.

2. Pengaruh dukungan manajemen terhadap kualitas audit internal aparat inspektorat dalam 
pengawasan keuangan daerah Kota Manado.

3. Pengaruh integritas terhadap kualitas audit internal aparat inspektorat dalam pengawasan keuangan daerah Kota Manado.

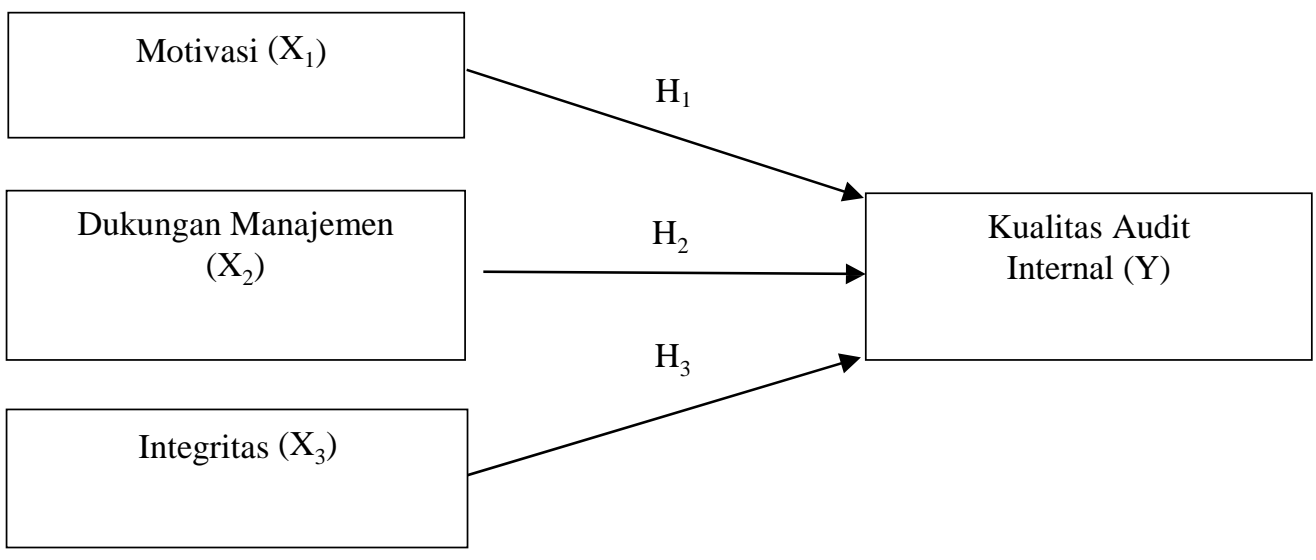

Gambar 1. Kerangka Konseptual

Motivasi menurut Purnomo (2012) merupakan proses yang dimulai dengan defisiensi fisiologis atau psikologis yang menggerakkan perilaku atau dorongan yang ditujukan untuk tujuan atau insentif. Perilaku seseorang pada hakikatnya ditentukan oleh motivasi atau keinginan. Motivasi sangat penting karena motivasi adalah hal yang menyebabkan, menyalurkan dan mendukung perilaku manusia, supaya mau bekerja giat dan antusias untuk mencapai tujuan atau hasil yang optimal. Hal ini mencegah terjadinya ketegangan/konflik sehingga akan membawa pencapaian tujuan organisasi secara efektif. Sehubungan dengan audit pemerintah, terdapat penelitian mengenai pengaruh rewards instrumentalities dan environmental risk factors terhadap motivasi rekan auditor independen untuk melaksanakan audit pemerintah.

Triarini dan Latrini (2016:1114) dalam penelitiannya tentang pengaruh kompetensi, skeptisme profesional, motivasi, dan disiplin terhadap kualitas audit Kantor Inspektorat Kabupaten/Kota Di Bali menyatakan bahwa semakin tinggi motivasi seorang auditor internal, maka akan meningkatkan kualitas audit aparat inspektorat Kota dan Kabupaten Bali.

Fernandez dan Rainey (2006) mengatakan dukungan manajemen dan komitmen untuk berubah memainkan peran penting dalam organisasi. Implementasi suatu sistem menuntut adanya komitmen dan peran aktif pemimpin atau top manajemen. Dalam konteks penelitian ini seperti yang diungkapkan oleh Sawyer (1995) dalam Mihret dan Yilmaz (2007) komitmen manajemen untuk melaksanakan rekomendasi audit dan dukungan penguatan audit internal sangat penting untuk keefektifan audit internal.

Dukungan manajemen merupakan salah satu faktor penting dalam keefektifan audit internal (Mihret dan Yilmaz, 2007; Cohen dan Sayag, 2010). Mihret dan Yilmaz (2007) menemukan rekomendasi audit tidak dilaksanakan oleh manajemen, sehingga berpengaruh terhadap keefektifan audit internal. Menurut Cohen dan Sayag (2010) dukungan manajemen tidak hanya pada pelaksanaan rekomendasi audit, tetapi juga pada pendanaan, pelatihan dan dukungan terhadap pelaksanaan audit contohnya menyewa tenaga ahli dari luar, menyediakan tempat kerja yang memadai dan memberikan penghargaan dalam meningkatkan kualitas audit. Hasil penelitian Masood dan Afzal (2016:27) menyatakan bahwa dukungan manajemen berpengaruh positif dan signifikan terhadap kualitas audit. Hal ini berarti jika manajemen sepenuhnya mendukung auditor, maka kualitas audit dapat ditingkatkan.

Integritas adalah sikap jujur, berani, bijaksana dan tanggung jawab auditor dalam melaksanakan audit. Integritas merupakan kualitas yang melandasi kepercayaan publik dan merupakan patokan bagi anggota dalam menguji semua keputusannya. Keempat unsur itu diperlukan untuk membangun kepercayaan dan memberikan dasar bagi pengambilan keputusan yang andal (Sukriah, 2009). Prihartono dkk (2019) juga menyebutkan bahwa integritas berpengaruh positif dan signifikan terhadap kualitas audit. Hal ini berarti bahwa dengan integritas yang tinggi, maka auditor dapat meningkatkan kualitas auditnya. 
Selanjutnya penelitian yang dilakukan oleh Yoanita dan Farida (2019) tentang pengaruh akuntabilitas, independensi auditor, kompetensi, due professional care, objektivitas, etika profesi, dan integritas auditor terhadap kualitas audit menunjukkan bahwa integritas auditor berpengaruh positif terhadap kualitas audit. Semakin tinggi integritas yang dimiliki auditor, berpengaruh terhadap tingkat kualitas audit yang dihasilkan.

\section{Metode Penelitian}

Jenis penelitian ini adalah penelitian kuantitatif yang berbentuk asosiatif menggunakan data primer dengan tujuan untuk menguji hipotesa tentang pengaruh motivasi, dukungan manajemen, integritas terhadap kualitas audit internal aparat inspektorat dalam pengawasan keuangan daerah. Teknik analisis yang digunakan dalam penelitian ini adalah analisis regresi linier berganda.

Responden yang menjadi sampel dalam penelitian ini adalah aparat pengawas internal yang bekerja pada Inspektorat Kota Manado. Populasi dalam penelitian ini berjumlah 55 orang. Jumlah sampel yang diambil adalah sebanyak 45 orang. Para responden tersebut terlibat langsung dalam kegiatan pemeriksaan, yang terdiri dari pejabat struktural, pejabat fungsional dan staf. Metode pengambilan sampel dalam penelitian ini adalah dengan cara purposive sampling.

\section{Hasil dan Pembahasan}

Data penelitian ini adalah data primer yang bersumber dari hasil pengisian kuesioner oleh para responden, yakni aparat inspektorat Kota Manado. Peneliti mengantarkan langsung kuesioner kepada responden untuk mengantisipasi terjadinya respond rate yang rendah pada saat pengembalian kuesioner.

Uji validitas digunakan untuk mengetahui kelayakan butir-butir dalam suatu daftar pertanyaan dalam mendefinisikan suatu variabel. Daftar pertanyaan ini pada umumnya mendukung suatu kelompok tertentu. Uji validitas dilakukan untuk setiap butir pertanyaan. Hasil rhitung dibandingkan dengan rtabel dimana $\mathrm{df}=\mathrm{n}-2$ dengan sig 5\%. Jika rtabel < rhitung maka valid (Sujarweni, 2016:239). Dalam penelitian ini, $r_{\text {tabel }}$ dengan menggunakan $\mathrm{df}=43$ (diperoleh dari sampel 45 dikurangi 2) dan tingkat signifikansi 5\% adalah sebesar 0,248. Hasil uji validasi menunjukkan bahwa semua item pertanyaan untuk variabel motivasi, dukungan manajemen, integritas dan kualitas audit internal memiliki kriteria valid karena masing-masing item pertanyaan mempunyai nilai rtabel < rhitung.

Reliabilitas (keandalan) merupakan ukuran suatu kestabilan dan konsistensi responden dalam menjawab hal yang berkaitan dengan kontruk-kontruk pertanyaan yang merupakan dimensi suatu variabel dan disusun dalam suatu bentuk kuesioner. Uji reliabilitas dapat dilakukan secara bersamasama terhadap seluruh butir pertanyaan. Jika nilai Alpha > 0,70 maka reliabel (Sujarweni, 2016:239). Hasil uji reliabilitas menunjukkan bahwa nilai Cronbach's Alpha untuk motivasi sebesar 0,898, dukungan manajemen sebesar 0,832, integritas sebesar 0,817, dan kecurangan laporan keuangan sebesar 0,826. Dengan demikian seluruh item pertanyaan yang digunakan untuk mengukur masingmasing variabel dalam penelitian ini dinyatakan reliabel. Hal ini terlihat dari nilai Cronbach's Alpha masing-masing variabel lebih dari 0,70 .

Uji normalitas bertujuan untuk mengetahui distribusi data dalam variabel yang digunakan dalam penelitian. Jika probabilitas $>0,05$ maka data penelitian berdistribusi normal, dan apabila probabilitas < 0,05 maka data penelitian dianggap tidak berdistribusi normal (Sujarweni, 2016:72). Hasil uji normalitas menggunakan uji Kolmogorov-smirnov menunjukkan bahwa koefisien Kolmogorov-Smirnov sebesar 0,114 dengan tingkat signifikansi sebesar 0,173. Nilai signifikansi ini lebih besar dari $\alpha 0,05(0,173>0,05)$. Hal ini menunjukkan bahwa data dalam variabel penelitian ini terdistribusi secara normal. Dengan demikian, sebaran data dalam variabel ini baik dan layak digunakan dalam penelitian.

Uji multikolinearitas menurut Sujarweni (2016:230) diperlukan untuk mengetahui ada tidaknya variabel independen yang memiliki kemiripan antar variabel independen dalam suatu model. Kemiripan antar variabel independen akan mengakibatkan korelasi yang sangat kuat. Uji VIF (Varians Inflation Factor) yang dihasilkan antara 1 - 10 maka tidak terjadi multkolinieritas. Hasil uji multikolinieritas diketahui pada nilai Tolerance tidak ada variabel independen yang memiliki nilai kurang dari 0,1 dan tidak ada tidak ada variabel independen memiliki nilai VIF lebih dari 10, yaitu nilai VIF untuk variabel motivasi $\left(\mathrm{X}_{1}\right)$ sebesar $1,620<10$ dan nilai tolerance $0,617>0,1$; nilai VIF 
untuk variabel dukungan manajemen $\left(\mathrm{X}_{2}\right)$ sebesar $1,438<10$ dan nilai tolerance $0,695>0,1$; nilai VIF untuk variabel integritas aparatur $\left(\mathrm{X}_{3}\right)$ sebesar $1,157<10$ dan nilai tolerance $0,865>0,1$. Jadi dapat disimpulkan bahwa data dalam penelitian ini terbebas dari masalah multikolinieritas.

Uji heteroskedastisitas diperlukan untuk menguji apakah persamaan regresi berganda terjadi kesamaan atau ketidaksamaan varian residual dari observasi yang satu dengan observasi yang lain. Persamaan regresi yang baik jika tidak terjadi heteroskedastisitas. Uji heteroskedastisitas dapat menggunakan uji Glesjer. Jika probabilitas signifikansi masing-masing variabel independen $>0,05$, maka dapat disimpulkan tidak terjadi heteroskedastisitas dalam model regresi (Sujarweni, 206:238). Uji heteroskedastisitas menghasilkan nilai signifikansi masing-masing variabel lebih besar dari 0,05, yaitu motivasi sebesar 0,124, dukungan manajemen sebesar 0,964, dan integritas sebesar 0,086. Sehingga dapat disimpulkan bahwa model regresi tidak mengandung adanya heteroskedastisitas.

Model regresi berganda dalam penelitian ini adalah untuk menguji pengaruh Motivasi $\left(\mathrm{X}_{1}\right)$, Dukungan Manajemen $\left(\mathrm{X}_{2}\right)$, dan Integritas $\left(\mathrm{X}_{3}\right)$ terhadap Kualitas Audit Internas (Y). Hasil analisis regresi berganda adalah sebagai berikut:

Tabel 1.

Hasil Analisis Regresi Berganda

\begin{tabular}{|ll|c|c|}
\hline \multirow{2}{*}{} & \multirow{2}{*}{ Model } & \multicolumn{2}{c|}{ Unstandardized Coefficients } \\
\cline { 3 - 4 } & (Constant) & 0,249 & Std. Error \\
\hline Motivasi $\left(\mathrm{X}_{1}\right)$ & 0,447 & 0,377 \\
Dukungan Manajemen $\left(\mathrm{X}_{2}\right)$ & 0,285 & 0,098 \\
Integritas $\left(\mathrm{X}_{3}\right)$ & 0,205 & 0,100 \\
\hline
\end{tabular}

Sumber : Hasil Olahan (2019)

Persamaan regresi berganda adalah sebagai berikut:

$\mathrm{Y}=\alpha+\beta 1 \mathrm{X}_{1}+\beta 2 \mathrm{X}_{2}+\beta 3 \mathrm{X}_{3}+e$

$Y=0,249+0,447 X_{1}+0,285 X_{2}+0,205 X_{3}+e$

Persamaan tersebut menunjukkan bahwa arah garis tersebut linear dan merupakan hubungan yang positif. Atau dengan kata lain bahwa ada pengaruh motivasi, dukungan manajemen, dan integritas terhadap kualitas audit internal. Jika semakin tinggi motivasi, dukungan manajemen dan integritas maka akan meningkatkan kualitas audit internal aparat inspektorat dalam pengawasan keuangan daerah Kota Manado, sebaliknya jika semakin rendah motivasi, dukungan manajemen dan integritas dapat mengurangi kualitas audit internal aparat inspektorat dalam pengawasan keuangan daerah Kota Manado.

Untuk mengetahui ada tidaknya pengaruh masing-masing variabel independen terhadap variabel dependen, dapat dilakukan dengan membandingkan $p$-value pada kolom t dengan tingkat signifikansi yang digunakan sebesar 5\% (Sujarweni, 2016:113). Hasil uji t pada output SPSS dapat dilihat pada Tabel berikut:

Tabel 2.

Hasil Uji Hipotesis

\begin{tabular}{|c|c|c|c|c|c|c|}
\hline & Model & $\begin{array}{r}\text { Unstan } \\
\text { Coeff }\end{array}$ & $\begin{array}{l}\text { ardized } \\
\text { ients }\end{array}$ & $\begin{array}{c}\text { Standardized } \\
\text { Coefficients }\end{array}$ & $\mathrm{t}$ & Sig. \\
\hline & & $\mathrm{B}$ & Std. Error & Beta & & \\
\hline & (Constant) & 0,249 & 0,377 & & 0,661 & 0,513 \\
\hline & Motivasi $\left(\mathrm{X}_{1}\right)$ & 0,447 & 0,098 & 0,476 & 4,579 & 0,000 \\
\hline & Dukungan & & & & & \\
\hline & Manajemen $\left(\mathrm{X}_{2}\right)$ & 0,285 & 0,100 & 0,281 & 2,866 & 0,007 \\
\hline & Integritas $\left(\mathrm{X}_{3}\right)$ & 0,205 & 0,051 & 0,351 & 3,994 & 0,000 \\
\hline
\end{tabular}

Sumber : Hasil Olahan (2019) 
Nilai thitung dari kompetensi $\left(\mathrm{X}_{1}\right)$ adalah positif 4,579 sehingga thitung $>$ tabel $(4,579>$ $2,020)$. Signifikansi dari variabel motivasi $\left(X_{1}\right)$ adalah sebesar 0,000 artinya $p$-value $<0,05$. Hal ini menunjukkan bahwa $\mathrm{H}_{1}$ diterima dan $\mathrm{H}_{01}$ ditolak, terbukti bahwa motivasi $\left(\mathrm{X}_{1}\right)$ berpengaruh positif dan signifikan terhadap kualitas audit internal $(\mathrm{Y})$. Nilai thitung dari dukungan manajemen $\left(\mathrm{X}_{2}\right)$ adalah positif 2,866 sehingga thitung $>$ ttabel $(2,866>2,020)$. Signifikansi dari variabel dukungan manajemen $\left(\mathrm{X}_{2}\right)$ adalah 0,007 artinya $p$-value $<0,05$. Hal ini menunjukkan bahwa $\mathrm{H}_{2}$ diterima dan $\mathrm{H}_{02}$ ditolak, terbukti bahwa dukungan manajemen $\left(\mathrm{X}_{2}\right)$ berpengaruh positif dan signifikan terhadap kualitas audit internal $(\mathrm{Y})$. Nilai thitung dari integritas $\left(\mathrm{X}_{3}\right)$ adalah positif 3,994 sehingga thitung > ttabel (positif 3,994 > 2,020). Signifikansi dari variabel integritas $\left(\mathrm{X}_{3}\right)$ adalah 0,000 artinya $p$-value < 0,05. Hal ini menunjukkan bahwa $\mathrm{H}_{3}$ diterima dan $\mathrm{H}_{03}$ ditolak, terbukti bahwa integritas $\left(\mathrm{X}_{3}\right)$ berpengaruh positif dan signifikan terhadap kualitas audit internal (Y).

Nilai koefisien determinasi atau adjust $\mathrm{R}^{2}$ adalah sebesar 0,706 atau 70,60\%. Angka tersebut berarti sebesar 70,60\% Kualitas Audit dapat dijelaskan oleh variabel Motivasi $\left(\mathrm{X}_{1}\right)$, Dukungan Manajemen $\left(\mathrm{X}_{2}\right)$, dan Integritas $\left(\mathrm{X}_{3}\right)$. Sedangkan sisanya $(100 \%-70,60 \%=29,40 \%)$ disebabkan oleh faktor-faktor lain diluar pengujian ini. Koefisien korelasi (R) sebesar 0,852 menunjukkan bahwa hubungan (korelasi) antara variabel independen dengan variabel dependen merupakan hubungan yang kuat. Artinya Motivasi $\left(\mathrm{X}_{1}\right)$, Dukungan Manajemen $\left(\mathrm{X}_{2}\right)$, dan Integritas $\left(\mathrm{X}_{3}\right)$ terhadap Kualitas Audit mempunyai hubungan yang kuat.

\section{Pengaruh Motivasi Terhadap Kualitas Audit Internal}

Hasil pengujian hipotesis pertama $\left(\mathrm{H}_{1}\right)$ menunjukkan bahwa motivasi berpengaruh positif terhadap kualitas audit internal aparat inspektorat dalam pengawasan keuangan daerah Kota Manado. Dengan demikian hipotesis 1 terdukung karena secara empirik terbukti.

Hasil pengujian ini selaras dengan konsep Goleman dan Carry (2001) bahwa motivasi akan membuat seseorang mempunyai semangat juang yang tinggi untuk meraih tujuan dan memenuhi standar yang ada. Dengan kata lain, motivasi akan mendorong seseorang, termasuk auditor, untuk berprestasi, komitmen terhadap kelompok serta memiliki inisiatif dan optimisme yang tinggi. Respon atau tindaklanjut yang tidak tepat terhadap laporan audit dan rekomendasi yang dihasilkan akan dapat menurunkan motivasi auditor untuk menjaga kualitas audit.

Hasil pengujian ini selaras dengan penelitian sebelumnya yang dilakukan oleh Hanjani dan Rahardja (2014) yang menyatakan bahwa motivasi berpengaruh positif terhadap kualitas audit. Hal ini menunjukkan bahwa semakin tinggi motivasi seseorang menyebabkan semakin baik pula kualitas audit. Hasil penelitian ini juga selaras dengan penelitian Azma, Nurazlina dan Julita (2017) menyatakan bahwa motivasi berpengaruh terhadap kualitas hasil audit inspektorat. Hal ini menunjukkan bahwa semakin tinggi motivasi aparat inspektorat, maka akan berpengaruh terhadap meningkatnya kualitas hasil audit aparat inspektorat. Hasil penelitian ini sejalan dengan penelitian yang dilakukan oleh Triarini dan Latrini (2016), Rosnidah (2018), dan Wati (2018) bahwa semakin tinggi tingkat motivasi yang dimiliki oleh oleh auditor aparat inspektorat dalam menjalankan audit, maka kualitas audit yang dihasilkan akan semakin baik. Motivasi yang tinggi tersebut akan berdampak pada tingginya kualitas audit internal dalam suatu organisasi. Dengan kata lain, jika auditor mempunyai motivasi yang tinggi dalam melaksanakan tugasnya, maka kualitas audit yang dihasilkan akan meningkat, begitu pula sebaliknya.

\section{Pengaruh Dukungan Manajemen Terhadap Kualitas Audit Internal}

Hasil pengujian hipotesis kedua $\left(\mathrm{H}_{2}\right)$ menunjukkan bahwa dukungan manajemen berpengaruh positif terhadap kualitas audit internal aparat inspektorat dalam pengawasan keuangan daerah Kota Manado. Dengan demikian hipotesis 2 terdukung karena secara empirik terbukti.

Hasil penelitian ini menunjukkan bahwa dukungan manajemen berpengaruh positif signifikan terhadap kualitas audit aparat inspektorat dalam pengawasan keuangan daerah Kota Manado. Hal ini menunjukkan pula bahwa kualitas audit dipengaruhi oleh dukungan manajemen. Artinya, jika manajemen puncak benar-benar mendukung auditor, maka kaulitas audit dapat ditingkatkan.

Hasil pengujian ini sesuai dengan penelitian sebelumnya yang dilakukan oleh Masood dan Afzal (2016) bahwa dukungan manajemen berpengaruh positif dan signifikan terhadap kualitas 
audit. Hal ini berarti jika manajemen sepenuhnya mendukung auditor, maka kualitas audit dapat ditingkatkan. Hal yang sama juga dinyatakan dalam penelitian Mahmudah (2016), Oktavia (2017), dan Wijayanti (2016) bahwa dukungan manajemen berpengaruh positif terhadap kualitas audit. Semakin besar upaya dalam rangka meningkatkan kapabilitas manajemen audit didukung dengan sumber daya yang memadai, standar kode etik yang dijalankan secara konsisten maka akan semakin baik kualitas audit yang dihasilkan. Hasil penelitian ini tidak selaras dengan penelitian Qodriyat dan Yazid (2019) bahwa dukungan manajemen tidak berpengaruh positif terhadap kualitas audit. Hal ini disebabkan upaya yang belum optimal dari pemerintah daerah dalam meningkatkan kapabilitas manajemen audit yang didukung oleh sumber daya yang memadai, standar kode etik yang dijalankan secara konsisten.

\section{Pengaruh Integritas Terhadap Kualitas Audit Internal}

Hasil pengujian hipotesis ketiga $\left(\mathrm{H}_{3}\right)$ menunjukkan bahwa integritas berpengaruh positif terhadap kualitas audit internal aparat inspektorat dalam pengawasan keuangan daerah Kota Manado. Dengan demikian hipotesis 3 terdukung karena secara empirik terbukti.

Hasil penelitian ini menunjukkan bahwa integritas berpengaruh positif signifikan terhadap kualitas audit internal aparat inspektorat dalam pengawasan keuangan daerah Kota Manado. Hal ini menunjukkan pula bahwa kualitas audit dipengaruhi oleh integritas. Artinya, integritas yang baik mampu meningkatkan kualitas audit. Semakin tinggi integritas dari auditor, maka semakin tinggi pula kualitas audit yang dihasilkan.

Hasil pengujian ini selaras dengan kode etik dan standar audit Pendidikan Pusat dan PPBP (2008) bahwa setiap auditor harus memiliki integritas dimana integritas dapat menerima kesalahan yang tidak disengaja dan perbedaan pendapat yang jujur, tetapi tidak dapat menerima kecurangan prinsip. Dengan integritas yang tinggi, maka auditor dapat meningkatkan kualitas hasil auditnya.

Hasil pengujian ini selaras dengan penelitian yang dilakukan oleh Yoanita dan Farida (2019) yang menunjukkan bahwa integritas auditor berpengaruh positif terhadap kualitas audit. Semakin tinggi integritas yang dimiliki auditor, berpengaruh terhadap tingkat kualitas audit yang dihasilkan. Hasil penelitian ini juga selaras dengan penelitian yang dilakukan oleh Badjuri (2017), Nurjanah dan Kartika (2016), Parasayu dan Rohman (2014), Pramono dan Mustikawati (2016), dan Prihartono dkk (2019) juga menyebutkan bahwa integritas berpengaruh positif dan signifikan terhadap kualitas audit. Hal ini berarti bahwa dengan integritas yang tinggi, maka auditor dapat meningkatkan kualitas auditnya. Auditor harus memiliki kepribadian yang dilandasi oleh unsur jujur, berani, bijaksana, dan bertanggung jawab untuk membangun kepercayaan guna memberikan dasar bagi pengambilan keputusan yang andal (Luthfi, 2013). Artinya setiap auditor harus memiliki integritas yang tinggi, agar dapat mengambil keputusan yang berkualitas termasuk dalam menghasilkan audit yang berkualitas.

\section{Kesimpulan dan Saran}

Berdasarkan hasil penelitian dan pembahasan dapat disimpulkan bahwa:

1. Motivasi berpengaruh positif signifikan terhadap kualitas audit internal aparat inspektorat dalam pengawasan keuangan daerah Kota Manado. Artinya dengan motivasi yang tinggi dapat meningkatkan kualitas audit aparat inspektorat, sebaliknya dengan motivasi yang rendah dapat mengurangi kualitas audit yang dihasilkan.

2. Dukungan manajemen berpengaruh positif signifikan terhadap kualitas audit internal aparat inspektorat dalam pengawasan keuangan daerah Kota Manado. Artinya jika manajemen puncak benar-benar mendukung auditor, maka kaulitas audit dapat ditingkatkan, sebaliknya jika tidak ada dukungan manajemen maka akan mengurangi kualitas audit yang dihasilkan.

3. Integritas berpengaruh positif signifikan terhadap kualitas audit internal aparat inspektorat dalam pengawasan keuangan daerah Kota Manado. Artinya, integritas yang baik mampu meningkatkan kualitas audit. Semakin tinggi integritas dari auditor, maka semakin tinggi pula kualitas audit yang dihasilkan. Sebaliknya, semakin rendah integritas, maka semakin rendah kualitas audit yang dihasilkan. 
Adapun saran yang dapat diberikan berdasarkan hasil penelitian yang telah dilakukan adalah sebagai berikut:

1. Saran bagi pemerintah daerah Kota Manado:

a) Motivasi sangat penting dalam meningkatkan kualitas audit internal, oleh karena itu perlu meningkatkan motivasi pada diri auditor dengan mengikuti kegiatan diklat dan seminar untuk meningkatkan kualitas audit aparat inspektorat sebagai auditor yang independen sehingga akan mengurangi ketidakpercayaan masyarakat terhadap kinerja pemerintah daerah.

b) Dukungan manajemen sangat penting dalam meningkatkan kualitas audit internal, oleh karena itu perlu membenahi semua sumber daya untuk lebih memadai. Salah satu upaya untuk menilai kinerja APIP yaitu dengan melakukan penilaian kapabilitas APIP. Level kapabilitas ini secara tidak langsung dapat memberikan gambaran mengenai tingkat efektifitas tata kelola suatu APIP karena salah satu kriteria dari suatu tata kelola yang baik adalah adanya pengembangan kapasitas dan kapabilitas organisasi.

c) Integritas sangat penting dalam meningkatkan kualitas audit internal, oleh karena itu aparat inspektorat Kota Manado agar lebih memahami SPAP sebagai pedoman dalam menjalankan auditnya lalu mewujudkannya dalam sikap kecermatan profesional, jujur, berani, bijaksana dan bertanggung jawab.

2. Saran bagi peneliti selanjutnya, agar memperdalam hasil temuan penelitian ini dengan menambah variabel-variabel yang menyebabkan kualitas audit internal.

\section{Daftar Pustaka}

Alim, M. Nizarul, Trisni Hapsari, dan Liliek Purwanti. 2017. Pengaruh Kompetensi Dan Independensi Terhadap Kualitas Audit dengan Etika Auditor Sebagai Variabel Moderasi. Simposium Nasional Akuntansi X Unhas Makasar 26-28 Juli 2017.

Azma, Mohammad Alfurqan, Nurazlina Nurazlina, dan Julita Julita. 2017. Pengaruh Motivasi, Pengetahuan Tentang Pengelolaan Keuangan Daerah Dan Intensitas Pembinaan Aparat Inspektorat Terhadap Kualitas Hasil Audit Inspektorat (Studi Empiris Pada Inspektorat Kota Pariaman Dan Kabupaten Padang Pariaman). (Doctoral dissertation, Riau University).

Badjuri, Achmad. 2017. Analisis Faktor-Faktor Yang Berpengaruh Terhadap Kualitas Pemeriksaan Auditor Intern Kota Semarang.

Cohen, Aaron dan Sayag. Gabriel. 2010. The Effectiveness of Internal Auditing: An Empirical Examination of its Determinants in Israeli Organisations. Australian Accounting Review, 54(20): 296-307.

De Angelo, L. Elizabeth. 1981. Auditor Size and Audit Quality. Journal of Accounting dan Economics. 3(3), 183-199.

Fernandez, Sergio dan Rainey, Hal. G. 2006. Managing Successful Organizational Change in the Public Sector. Public Administration Review, 168-176.

GAO. 2005. Performance Measurement and Evaluation: Definitions and Relationships.

Goleman, Daniel dan Carry Cherniss. 2001. The Emotionally Intelligent Workplace: How to Select For, Measure, and Improve Emotional Intelligence in Individuals Groups and Organisations.

Hanjani, Andreani dan Rahardja Rahardja. 2014. Pengaruh Etika Auditor, Pengalaman Auditor, Fee Audit, Dan Motivasi Auditor Terhadap Kualitas Audit (Studi pada Auditor KAP Di Semarang). Diss. Fakultas Ekonomika dan Bisnis.

Luthfi, Yuga. 2013. Pengaruh Objektivitas dan Integritas Auditor Internal Terhadap Kualitas Audit: Studi Kasus Pada Inspektorat Daerah Se-Bandung Raya. Diss. Universitas Pendidikan Indonesia.

Masood, A., dan Afzal, M. 2016. Determinants Of Audit Quality In Pakistan. Journal of Quality and Technology Management, 12, 25-49.

Mihret, Dessalegn. Getie, dan Yismaw Anderajew. Wondim. 2007. Internal Audit Effectiveness: An Ethiopian Public Sector Case Study. Managerial Auditing Journal, 22 No. 5, 470-484.

Nomor, Peraturan Presiden. Tahun 2014 Tentang Sistem Akuntabilitas Kinerja Instansi Pemerintah. Jakarta: Sekretariat Negara (29).

Nurjanah, Irwanti Bunga, dan Andi Kartika. 2016. Pengaruh Kompetensi, Independensi, Etika, Pengalaman Auditor, Skeptisme Profesional Auditor, Objektifitas dan Integritas terhadap 
Kualitas Audit (Studi Pada Kantor Akuntan Publik Di Kota Semarang). Dinamika Akuntansi Keuangan dan Perbankan, 5(2).

Parasayu, Annisa, dan Abdul Rohman. 2014. Analisis Faktor-Faktor Yang Mempengaruhi Kualitas Hasil Audit Internal (Studi Persepsi Aparat Intern Pemerintah Kota Surakarta dan Kabupaten Boyolali). Diponegoro Journal of Accounting, 3(2), 165-174.

Pendidikan, Pusat, dan Pelatihan Pengawasan Badan Pengawasan Keuangan. Pembangunan. 2008. Diklat Pembentukan Auditor Ahli, Kode Etik dan Standar Audit, Edisi Kelima, Jakarta.

Pramono, Oentung, dan Rr Indah Mustikawati. 2016. Pengaruh Locus Of Control, Due Professional Care dan Integritas Terhadap Kualitas Audit (Studi Empiris Pada Kantor Akuntan Publik Di Daerah Istimewa Yogyakarta). Jurnal Profita: Kajian Ilmu Akuntansi, 4(5).

Prihartono, Prihartono, Theresia Theresia, dan Sekar Mayangsari. 2019. Pengaruh Integritas, Objektivitas, dan Kompetensi Auditor Internal Terhadap Efektivitas Audit Internal Dengan Gaya Kepemimpinan Demokrasi Sebagai Variabel Moderasi Pada Inspektorat Jenderal Kementerian Dalam Negeri. Jurnal Magister Akuntansi Trisakti, 5(1), 63-88.

Purnomo, Soleh. 2012. Analisis pengaruh Kompesasi Dan Motivasi Terhadap Kinerja Karyawan Pada Balai latihan Pendidikan. Magister Manajemen. 1(2).

Qodriyat, Yodi Ero, dan Helmi Yazid. 2019. Determinan Kualitas Audit Studi Empiris Pada Inspektorat Pemerintah Provinsi Banten. Jurnal Riset Akutansi Tirtayasa. 3(2), 273-289.

Rosnidah, Ida. 2018. Model Pengukuran Kualitas Audit Internal. EKUITAS (Jurnal Ekonomi dan Keuangan), 17(3), 299-317.

Simanjuntak, Pieter. 2008. Pengaruh Time Budget Pressure Dan Resiko Kesalahan Terhadap Penurunan Kualitas Audit (Reduced Audit Qaulity)(Studi Empiris Pada Auditor Kap Di Jakarta). Diss. Program Sarjana Universitas Diponegoro.

Sujarweni, V. Wiratna. 2016. Kupas Tuntas Penelitian Akuntansi dengan SPSS. Yogyakarta: Pustaka Baru Press.

Sukriah, I. Akram dan Biana Adha Inapty. 2009. Pengaruh Pengalaman Kerja, Independensi, Objektivitas, Integritas, dan Kompetensi terhadap Kualitas Hasil Pemeriksaan. Simposium Nasional Akuntansi, 12, 3-9.

Triarini, Dewa Ayu Wini, dan Made Yenni Latrini. 2016. Pengaruh Kompetensi, Skeptisme Profesional, Motivasi, dan Disiplin Terhadap Kualitas Audit Kantor Inspektorat Kabupaten/Kota Di Bali. E-Jurnal Akuntansi, 1092-1119.

Turangan, Grace. 2016. Faktor - Faktor Yang Mempengaruhi Kualitas Audit Pada Inspektorat Provinsi Sulawesi Utara. Jurnal Accountability, 5(2), 119-140.

Undang-Undang Nomor 17 Tahun 2003 Tentang Keuangan Negara.

Wati, Sri Yuna. 2018. Pengaruh Kompetensi Dan Motivasi Auditor Terhadap Kualitas Audit Pada Kantor Inspektorat Kabupaten Rokan Hulu. Cano Ekonomos, 7(2), 1-8.

Wolajan, Finneke. 2018. Pemkot Manado Raih Opini WTP, Mor Harap Perangkat Daerah Tak Berpuas Diri. http://manado.tribunnews.com/2018/06/04/pemkot-manado-raih-opini-wtpmor-harap-perangkat-daerah-tak-berpuas-diri.

Yoanita, Shela, dan F. Farida. 2019. Pengaruh Akuntabilitas, Independensi Auditor, Kompetensi, Due Professional Care, Objektivitas, Etika Profesi dan Integritas Auditor Terhadap Kualitas Audit. In Prosiding Seminar Nasional \& Call For Paper (pp. 289-301). 